\title{
Proceeding
}

8th INSHS International Christmas Sport Scientific Conference, 5-7 December 2013. International Network of Sport and Health

Science. Szombathely, Hungary

\section{Speed parameters in female pole vault}

\author{
PETER KRSKA, ANDRE HUBINAK, JAROMIR SEDLACEK \\ Department of Physical Education and Sport, Faculty of Education, Catholic University, Slovakia
}

\begin{abstract}
Krska, P., Hubinak, A. \& Sedlacek, J. (2014). Speed parameters in female pole vault. J. Hum. Sport Exerc., 9(Proc1), pp.S257-S262. The speed parameters in pole vault of females were analysed. Research subject population was formed by pole vault females with personal best performances from 380 to $483 \mathrm{~cm}$. Female vaulters of higher performance level reach also higher centre of gravity horizontal speed at the end of takeoff and by more effective transition on pole they lose less of this speed like vaulters of lower performance level. It was found that differences in vertical centre of gravity speed at finishing in phases of swing up with turn and extension show better movement activity on pole of female vaulters with the higher performance level. Key words: FEMALE, POLE VAULT, SPEED, CENTRE OF GRAVITY.
\end{abstract}

Corresponding author. Department of Physical Education and Sport, Faculty of Education, Catholic University. Slovakia. E-mail: jaromir.sedlacek47@gmail.com 8th INSHS International Christmas Sport Scientific Conference, 5-7 December 2013. International Network of Sport and Health Science. Szombathely, Hungary.

JOURNAL OF HUMAN SPORT \& EXERCISE ISSN 1988-5202

(c) Faculty of Education. University of Alicante doi:10.14198/jhse.2014.9.Proc1.07 


\section{INTRODUCTION}

Pole vault is the only athletic event in which the performance is reached with use of tool. The pole use put this event away from fundamental locomotion and adjoins it to complex athletic events. The movement activity is realised in two basic parts; the first is approach ended with take-off and the second is the movement of jumper on the pole.

Very important precondition for high performance use is to reach the approach as fast as possible, mainly at the end of approach and its' finishing with explosive take-off and with rational transition on the pole. McGinnise (1997) proves that take-off effectiveness is manifested in holding or even in increase of kinetic energy gained with approach.

Approach velocity and take-off form kinetic energy which pole-vaulter by exact and energy planting the pole in the take-off box transmits on the pole. At take-off moment the pole starts to bend and thus is shortened the distance between grip and the end of the pole. Pole elasticity thus enables actually to pass easier and faster through vertical line and this also enables to have higher grip on the pole. The pole in the phase of bending cumulate kinetic energy and at period of straightening phase returns it at vertical centre of gravity acceleration of pole-vaulter. At time of pole straightening is important active muscle pole-vaulter work, for direction of catapulting must be the same with direction of the pole-vaulter centre of gravity; otherwise it comes to forces breakdown and it courses lost of peak height of the centre of gravity (CGv). The polevaulter by his activity on the pole influences common movement rhythm of movement; through his adequate activity on pole can be increased vertical centre of gravity peak.

Run-up velocity at two five meters long sectors before take-off and its influence on performance were observed, except others, by Bojko - Nikonov (1989), Adamczewski - Dickwach (1991), Bartonietz - Petrov Wetter (1994), Adamczewski - Perltová (1997), Krška (2010).

In the sport performance structure of female pole-vaulters (fig 1) there are from the point of kinetic parameters the speed characteristics of movement activity have very important role (Krška, 2001, 2008).

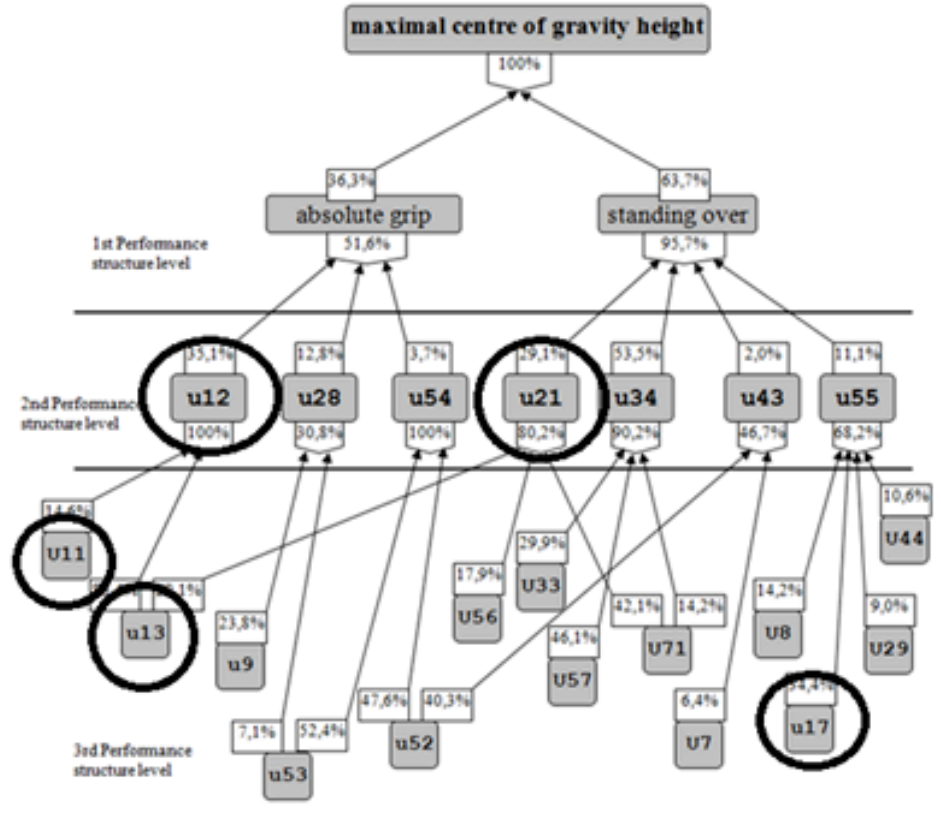

Legend of watched speed parameters in fig 1

\begin{tabular}{|l|l|}
\hline \multicolumn{2}{|l|}{ Horizontal speed of centre of gravity at moment } \\
\hline $\mathbf{u l l}$ & tread-down on take-off \\
\hline $\mathbf{u l 2}$ & end of take-off \\
\hline $\mathbf{u 1 3}$ & speed lost during take-off \\
\hline Vertical speed of centre of gravity at the end of moment \\
\hline $\mathbf{u 1 7}$ & hanging position \\
\hline $\mathbf{u 2 1}$ & extension with turn \\
\hline
\end{tabular}

Figure 1. Relations and quantifications of parameters in female pole vault sport performance structure with regard of speed parameters (Krska, 2008) 
Objectives

Aim of this contribution was to analyse course of horizontal and vertical centre of gravity speed of female pole-vaulters.

Tasks:

1. Realise kinematic analyse of jumps of watched females

2. Analyse and compare gained speed parameters of female pole-vaulters of different sport performance

\section{MATERIAL AND METHODS}

This research was performed in 2004 - 2006 on the meetings Golden spiked shoes in Ostrava, Czech Republic. Kinetic parameters were gained by two-dimension analyser Consport Motion Analysis System (CMAS). There are involved 19 female pole-vaulters with the sport performance $380-483 \mathrm{~cm}$. All watched top-level female pole-vaulters (group S) were divided on 2 smaller groups; lower sport performance group (S1) and higher sport performance group (S2). Fundamental statistic characteristic can be seen in tables 1, 2 and 3 . In this contribution are used logical methods, mostly analyse, comparison and induction.

\section{RESULTS}

Table 1. Statistical characteristics of kinetic parameters of the whole group S, sport performance $380-483$ $\mathrm{cm}(\mathrm{S}, n=19)$

\begin{tabular}{|l|l|l|l|l|l|l|}
\hline \multicolumn{2}{|l|}{ Parameter $(u)$} & {$[\mathrm{unit}]$} & $\mathrm{x}$ & $\mathrm{x}_{\mathrm{max}}$ & $\mathrm{x}_{\text {min }}$ & $\mathrm{s}$ \\
\hline$u 1$ & Maximal centre of gravity height & {$[\mathrm{cm}]$} & 448,03 & 490,50 & 408,10 & 23,07 \\
\hline$u 2$ & Absolute height of upper arm grip & {$[\mathrm{cm}]$} & 403,11 & 420,00 & 385,00 & 10,86 \\
\hline$u 3$ & Standing over (peak height) & {$[\mathrm{cm}]$} & 44,92 & 70,50 & 11,20 & 16,24 \\
\hline
\end{tabular}

Table 2. Statistical characteristics of kinetic parameters of the lower sport performance group $\$ 1380-430$ $\mathrm{cm}(\mathrm{S} 1, n=9)$

\begin{tabular}{|l|l|l|l|l|l|l|}
\hline \multicolumn{2}{|l|}{ Parameter $(u)$} & {$[\mathrm{unit}]$} & $\mathrm{x}$ & $\mathrm{x}_{\mathrm{max}}$ & $\mathrm{x}_{\text {min }}$ & $\mathrm{s}$ \\
\hline$u 1$ & Maximal centre of gravity height & {$[\mathrm{cm}]$} & 428,36 & 441,14 & 408,10 & 12,28 \\
\hline$u 2$ & Absolute height of upper arm grip & {$[\mathrm{cm}]$} & 395,89 & 406,00 & 385,00 & 6,81 \\
\hline$u 3$ & Standing over (peak height) & {$[\mathrm{cm}]$} & 32,47 & 49,10 & 11,20 & 10,83 \\
\hline
\end{tabular}

Table 3. Statistical characteristics of kinetic parameters of the higher sport performance group S2, with 440 $-483 \mathrm{~cm}(S 2, n=10)$

\begin{tabular}{|l|l|l|l|l|l|l|}
\hline \multicolumn{2}{|l|}{ Parameter $(u)$} & {$[\mathrm{unit}]$} & $\mathrm{x}$ & $\mathrm{x}_{\mathrm{max}}$ & $\mathrm{x}_{\text {min }}$ & $\mathrm{s}$ \\
\hline$u 1$ & Maximal centre of gravity height & {$[\mathrm{cm}]$} & 465,73 & 490,50 & 449,30 & 13,98 \\
\hline$u 2$ & Absolute height of upper arm grip & {$[\mathrm{cm}]$} & 409,60 & 420,00 & 395,00 & 9,79 \\
\hline$u 3$ & Standing over (peak height) & {$[\mathrm{cm}]$} & 56,13 & 70,50 & 33,30 & 11,35 \\
\hline
\end{tabular}




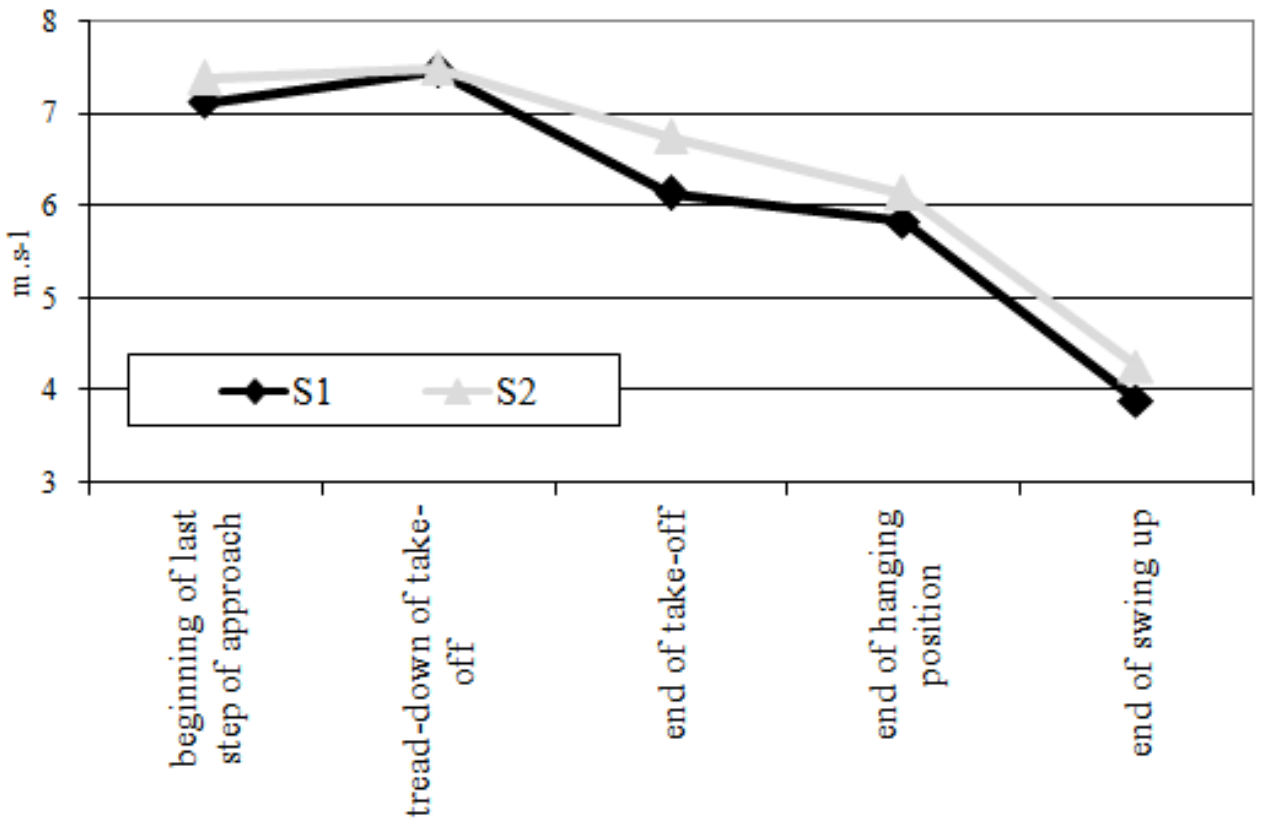

Figure 2. Course comparison of horizontal speed of centre of gravity

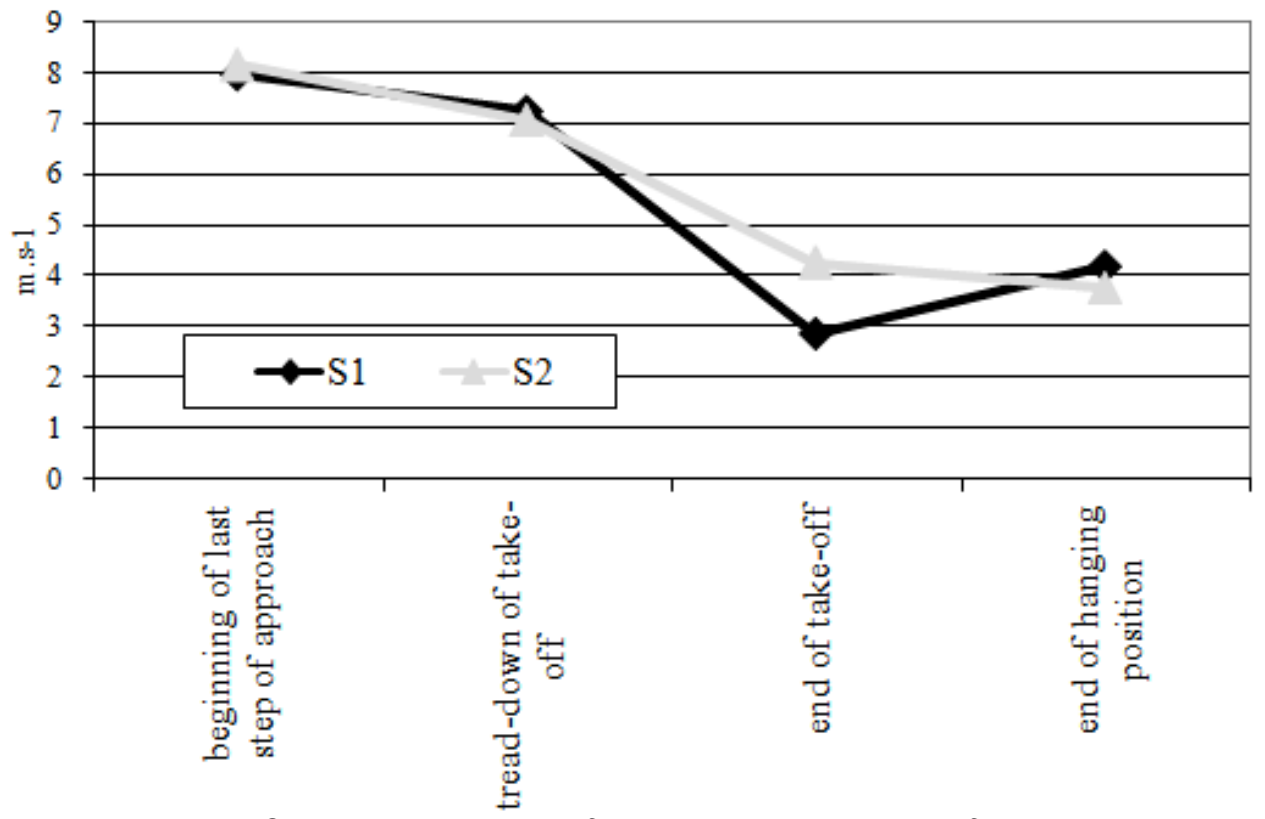

Figure 3. Course comparison of horizontal point speed of higher arm grip 


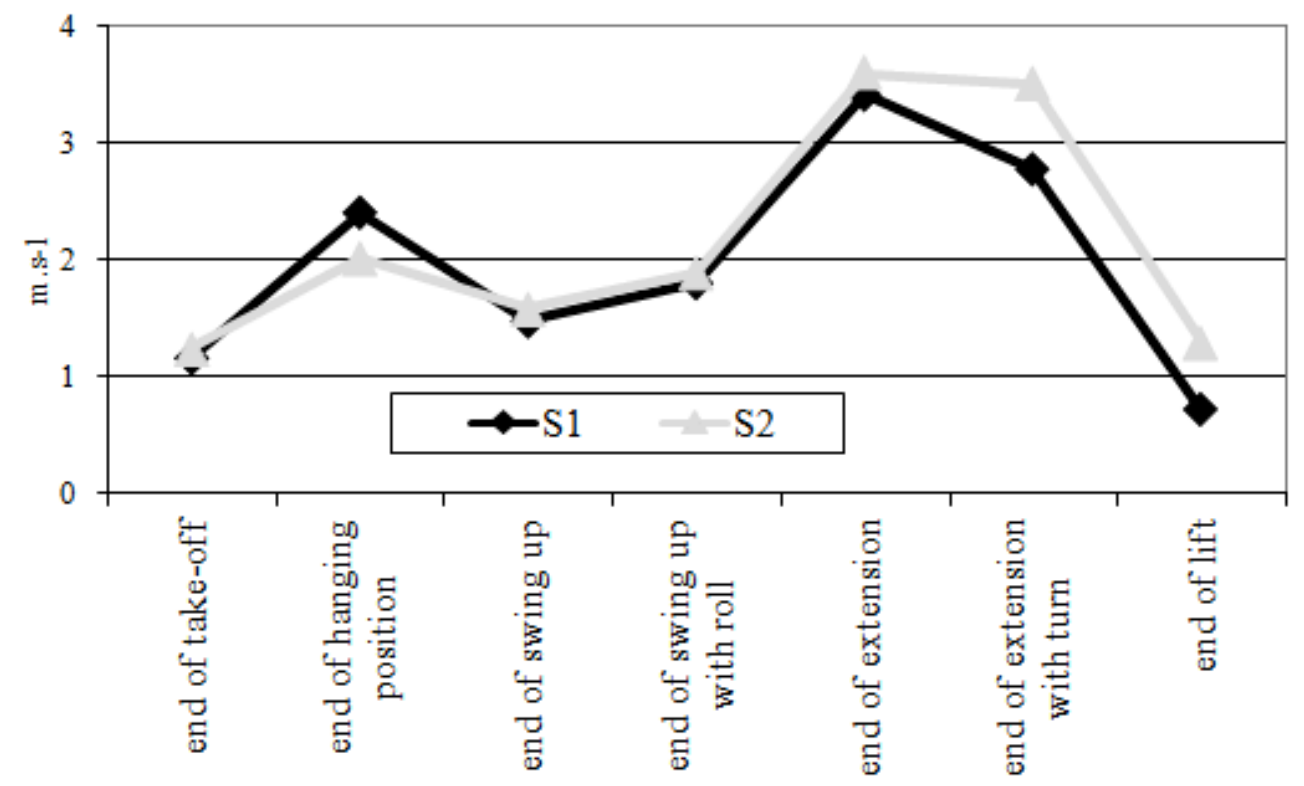

Figure 4. Course comparison of vertical speed of centre of gravity

\section{DISCUSSION}

Average horizontal CGv speed of our female pole-vaulters at the beginning of last step reached 7.27 m.s-1. At the first touchdown moment of take-off the velocity even slightly increases on average value 7.46 m.s-1. The fastest $(8,48 \mathrm{~m} . \mathrm{s}-1)$ is always the one with the best sport performance result, S.D. $(483 \mathrm{~cm})$. During take-off reached pole-vaulters average lost of velocity $1.02 \mathrm{~m} . \mathrm{s}-1$. Better value about technique effectiveness seems to be percentage lost of vertical CGv speed during take-off; average value is minus $13.4 \%$ from the velocity reached during approach. After transmission on pole we can watch relatively high values of CGv horizontal speed at moment of end of hanging position (average value is $6.00 \mathrm{~m} . \mathrm{s}-1$ ). At the moment of the end of swing up we watch their average velocity on the level 4.09 m.s-1.

Like supported parameter of pole-vaulter transmission on pole we watched horizontal speed the point of upper arm grip that during take-off suddenly decrease of $3.56 \mathrm{~m} . \mathrm{s}-1$. This average lost in percentage is $49.4 \%$.

During pole-vaulter activity on pole is important gained vertical CGv speed. First values are registered after the end of take-off when average vertical CGv speed reaches average value 1.20 m.s-1. During following phases of hanging position, swing up and roll this value changes only slightly and have oscillating character. Considerable growth of vertical speed of the CGv can be watched after beginning of pole extension. After finishing of the phase of extension reach pole-vaulters average value $3.51 \mathrm{~m} . \mathrm{s}-1$. At the moment of peak height the average vertical speed value is on the level $3.16 \mathrm{~m} . \mathrm{s}-1$.

The average horizontal CGv speed of higher sport performance pole-vaulters (S2) slightly overreaches values reached by pole-vaulters of lower sport performance (S1). The highest difference can be watched at the moment of take-off end (average is $0.62 \mathrm{m.s}-1$ ), when pole-vaulters S2 lost from horizontal CGv speed during transmission on pole only 0.74 m.s-1, while S1 lost 1.33 m.s-1 (fig 2). 
Similar course with only slightly different values can be watched (fig 3) also at horizontal speed of upper arm grip. The most comprehensive difference between our groups are watched at moment of the end of take-off (difference is 1.41 m.s-1), when in group S2 we watched average speed 4.28 m.s-1 and in group S1 2.87 m.s-1. The difference at speed lost of upper arm grip during the whole take-off period is even slightly higher and represent average value 1.57 m.s-1.

Higher values of vertical CGv speed we found in the group of higher sport performance level (S2). The group of lower sport performance level (S1) reached higher velocity only at moment of hanging position (difference plus 0.40 m.s-1) that we consider like not effective (fig 4). Significant difference in average value it is 0.72 m.s-1 in favour of S2 group we watch at the end of roll and $0.56 \mathrm{~m} . \mathrm{s}-1$ at the end of extension that shows on better work on pole of higher sport performance pole-vaulters (S2).

\section{CONCLUSION}

Speed parameters enable us to evaluate effectiveness of movement activity of female pole-vaulters during phases of approach and work on pole.

Found differences in horizontal centre of gravity speed at moment of the end of take-off and parallel watched lost during take-off phase show on more effective transmission on pole of higher sport performance pole-vaulters. Found differences in vertical speed at the end of phases of roll and extension with turn manifest the better activity on pole of again higher sport performance pole-vaulters.

Presented differences in among not very different values of watched groups of female pole-vaulters show on possibilities and training orientation of further performance increase.

\section{REFERENCES}

1. Adamczewski, H. \& Dickwach, H. (1991). Zum Zusammenhang zwischen Anlaufgeschwindigkeit und Sprungleistung. In: Leichtathletik, 19, pp.15-18.

2. Adamczewski, H. \& Perlt, B. (1997). Run-up velocities of female and male pole vaulting and some technical aspects of women's pole vault. In: New studies in athletics. Monaco: IAAF, 12(1), pp.6377.

3. Bartonietz, K., Petrov, V. \& Wetter, J. (1994). Zum Stabhochsprung der Frauen. In: Leichtathletik, 15, pp.15-18.

4. Bojko, V. \& Nikonov, I. (1989). Novoe v prižke c šestom. In: Legkaja atletikano, 10, pp.30-31.

5. Krška, P. (2001). Intraindividuálny efekt tréningového zat’aženia na zmeny technickej pripravenosti, pohybovej a športovej výkonnosti v skoku o žrdi žien. Dizertačná práca. Banská Bystrica: FHV UMB.

6. Krška, P. (2008). Vývoj modelu kinematickej štruktúry športového výkonu v skoku o žrdi žien. In: Elektronický zborník z medzinárodnej konferencie: Atletika. Nitra: UKF PF KTVŠ, pp.68-73.

7. Krška, P. (2011). Les vitesses de la courses d'élan en saut à la perche chez les hommes et les femmes In: Revue internationale des Sciences humaines et naturelles.: Fribourg: S.É.C.T. Association Internationale Sciences, Éducation, Culture, Traditions. Fribourg - Suisse, 1(2), pp.8391.

8. Mcginnis, P.M. (1997). Mechanics of pole vault take-off. In: New studies in athletics. Monaco: IAAF, 12(1), p.43-46. 